\section{Performance of Plug-grown Geranium Seedlings Preconditioned with Nitrogen Fertilizer or Low-temperature Storage}

\author{
Mark P. Kaczperski', Allan M. Armitage, and Pamela M. Lewis \\ Department of Horticulture, University of Georgia, Athens, GA 30602
}

Additional index words. Pelargonium $\times$ hortorum, postharvest, stress

\begin{abstract}
Pelargonium $\times$ hortorum L.H. Bailey 'Scarlet Elite' seedlings were grown in plugs from seed to transplant size. About 14 days before attaining transplant size, seedlings were exposed to various fertility or temperature regimes (preconditioning treatments), then stored for 1 to 3 weeks at $5 \mathrm{C}$. Seedlings receiving $150 \mathrm{mg} \mathrm{N} / \mathrm{liter}$ before storage flowered sooner and required less crop time (days to flower - days in storage) than those receiving 0,75 , or $300 \mathrm{mg}$. Temperature preconditioning at 10 or $15 \mathrm{C}$ delayed flowering compared to preconditioning at 20C. Final plant height and dry weight were not adversely affected by varying $\mathrm{N}$ levels or temperature during preconditioning. Preconditioning seedlings with $300 \mathrm{mg}$ N/liter resulted in seedling mortality rates up to $16 \%$ after 7 days' storage. Low temperature or fertility were not effective preconditioning treatments. Best results were attained by preconditioning seedlings with $150 \mathrm{mg}$ N/liter.
\end{abstract}

Plugs have improved production efficiency of bedding plants greatly, but their use needs to be refined and optimized. Although plants should be transplanted to final containers when they reach transplantable size, lack of time, equipment, or labor often delays transplanting. Plug storage, or holding plugs until the grower is able to use the plants, is gaining popularity in industry. Delayed transplanting can result in overgrown plants in plug trays and delayed flowering if plants are held in the greenhouse too long (Holcomb and White, 1987; Hopper and Carlson, 1985). Flowering delay is avoided in seed geraniums if the greenhouse is $\leq 18 \mathrm{C}$ (White and Quatchak, 1985). Recent research suggests that plugs may be held in a cold-storage facility where better temperature control is achieved (Heins et al., 1995; Kaczperski and Armitage, 1992; Lange et al., 1991).

Preconditioning or hardening of floricultural crops commonly is used to promote stress tolerance. Reducing water and fertility levels near the end of the production cycle enable bedding plants to withstand the stress of shipping and marketing (Armitage and Kowalski, 1983a, 1983b; Carlson et al., 1992). Nights of 10 to $12 \mathrm{C}$ at visible bud improves tolerance to fluctuating temperatures during shipping (McCann, 1991). Storage of plugs also induces stress. This stress may translate to delayed flowering and reduced plant quality (AlHemaid and Koranski, 1990; Heins et al., 1995; Kaczperski and Armitage, 1992). If the plants are hardened properly or preconditioned before shipping or storage, they may withstand low-temperature stress without detrimental effects. This experiment separately

Received for publication 3 July 1995. Accepted for publication 15 Feb. 1996. The cost of publishing this paper was defrayed in part by the payment of page charges. Under postal regulations, this paper therefore must be hereby marked advertisement solely to indicate this fact.

${ }^{1}$ Current address: Box 1192, Okemos, MI 48805. examined the effectiveness of $\mathrm{N}$ fertilization and temperature in preconditioning geranium seedlings before storage or simulated shipping.

\section{Materials and Methods}

Geranium seeds ('Scarlet Elite') were sown in plugs ( 406 per tray, $1.5 \times 1.5 \times 2.2 \mathrm{~cm}$ ) filled with a commercial peat-lite substrate (Fison's Sunshine Basic Mix \#2, Bellevue, Wash.). Seeds were germinated in a growth chamber at $25 \pm 2 \mathrm{C}$ and $100 \mu \mathrm{mol} \cdot \mathrm{m}^{-2} \cdot \mathrm{s}^{-1}$ irradiance from fluorescent and incandescent bulbs $(85: 15$ input wattage, respectively) with a 24 -h photoperiod. Seven days after sowing, seedlings were moved to a greenhouse set at $18 \mathrm{C}$ (night) and 21C (day). Seedlings were fertilized at every irrigation with $100 \mathrm{mg}$ N/liter using a commercial formulation $(15 \mathrm{~N}-7 \mathrm{P}-14 \mathrm{~K})$ (Grace-Sierra, Fogelsville, Pa.) that consisted of $47 \% \mathrm{~N}$ in the $\mathrm{NH}_{4}$ form. Twenty-six days after sowing, the seedlings (two- to three-leaf stage) were treated with various $\mathrm{N}$ levels or growing temperatures. The first set of seedlings received $0,75,150$, or $300 \mathrm{mg} \mathrm{N} / \mathrm{liter}$, from $15 \mathrm{~N}-7 \mathrm{P}-14 \mathrm{~K}$, for 14 days. The second set was placed in growth chambers maintained at 10,15 , or $20 \pm 2 \mathrm{C}$, irradiance of 200 $\mu \mathrm{mol} \cdot \mathrm{m}^{-2} \cdot \mathrm{s}^{-1}$, and 18 -h photoperiod for 14 days. After treatments, seedlings had attained transplantable size (four to five leaves) and were placed in cold storage at $5 \mathrm{C}$ for $0,7,14$, or 21 days under 24-h irradiance of $15 \mu \mathrm{mol} \cdot \mathrm{m}^{-2} \cdot \mathrm{s}^{-1}$ from incandescent lamps. After storage, seedlings were potted in $490-\mathrm{ml}(10-\mathrm{cm})$ plastic pots filled with the same commercial substrate as before and grown to anthesis in the greenhouse. Fertility levels were maintained by applications of $200 \mathrm{mg} \mathrm{N} / \mathrm{liter}$, using the same $15 \mathrm{~N}-7 \mathrm{P}-14 \mathrm{~K}$ formulation as before. Seedling mortality rates were determined for each treatment by counting the number of dead seedlings per treatment after removal from storage. At anthesis, plants were evaluated for effects of preconditioning and storage period on days to flower, crop time (days to flower - days in storage), plant height (measured from soil line to top of plant canopy), and shoot dry weight. Statistical analyses of variance (ANOVA) were performed using the ANOVA procedure in SAS (SAS for Windows, ver. 6.1, SAS Inst., Cary, N.C.).

\section{Results and Discussion}

Varying the $\mathrm{N}$ levels before storage affected the seedlings' ability to withstand the stress of storage. Seedlings receiving $300 \mathrm{mg}$ $\mathrm{N} /$ liter had high mortality rates during storage (Fig. 1), with an average rate of $18 \%$ over all storage durations. Tests indicated the presence of Pythium. Seed geraniums displayed increased susceptibility to Pythium as fertility levels increased (Gladstone and Moorman, 1989). Mortality rates ranged from $0 \%$ to $3 \%$ when temperature was used to precondition the seedlings (data not shown).

Flowering was delayed in all plants that received $0 \mathrm{mg} \mathrm{N} / \mathrm{liter}$ for the 14 days of preconditioning (Fig. 2a). Geraniums respond favorably to high levels of fertilizer as long as soluble salt levels are not allowed to build (Armitage and Kaczperski, 1992). Without the stress of storage, seedlings under higher fertility regimes grew faster, allowing them to flower up to 11 days sooner than those at lower fertility levels. However, when stressed by storage, plants receiving $300 \mathrm{mg}$ N/liter flowered later than those receiving only $150 \mathrm{mg} \mathrm{N} /$ liter. Postharvest life of foliage, flowering, and bedding plants was reduced by high or supraoptimal fertilizer levels during production (Nell and Barrett, 1990). The geranium seedlings receiving $300 \mathrm{mg} \mathrm{N} /$ liter in our study flowered later, presumably because the plants did not adapt to the low-temperature stress of storage, unlike the plants receiving $150 \mathrm{mg}$.

Crop time was shorter for plants preconditioned with $\mathrm{N}$ than those receiving $0 \mathrm{mg} / \mathrm{liter}$ (Fig. 2b). Seedlings preconditioned with 150 $\mathrm{mg} \mathrm{N} /$ liter required 22 fewer days in the production environment than seedlings preconditioned with $0 \mathrm{mg} \mathrm{N} /$ liter after 14 days storage. Geraniums require a constant nutrient supply to maintain steady growth (Armitage and Kaczperski, 1992). Seedlings receiving 0 mg $\mathrm{N} /$ liter before storage were stressed twice by insufficient nutrition and low temperature. These combined stresses could have affected subsequent growth, resulting in an additional time requirement in the production environment.

Even when preconditioned with $\mathrm{N}$, seedlings required more time in the production environment after 14 and 21 days' storage than seedlings not stored (Fig. 2b). Seedlings receiving $150 \mathrm{mg} \mathrm{N} / \mathrm{liter}$ required 20 additional days in the production environment when stored for 21 days compared to similarly preconditioned seedlings that were not stored. Stored petunia (Petunia $\times$ hybrida Vilm.) seedlings did not require additional time in the production environment when compared with unstored seedlings (Kaczperski and Armitage, 1992). However, petunia seedlings continue 


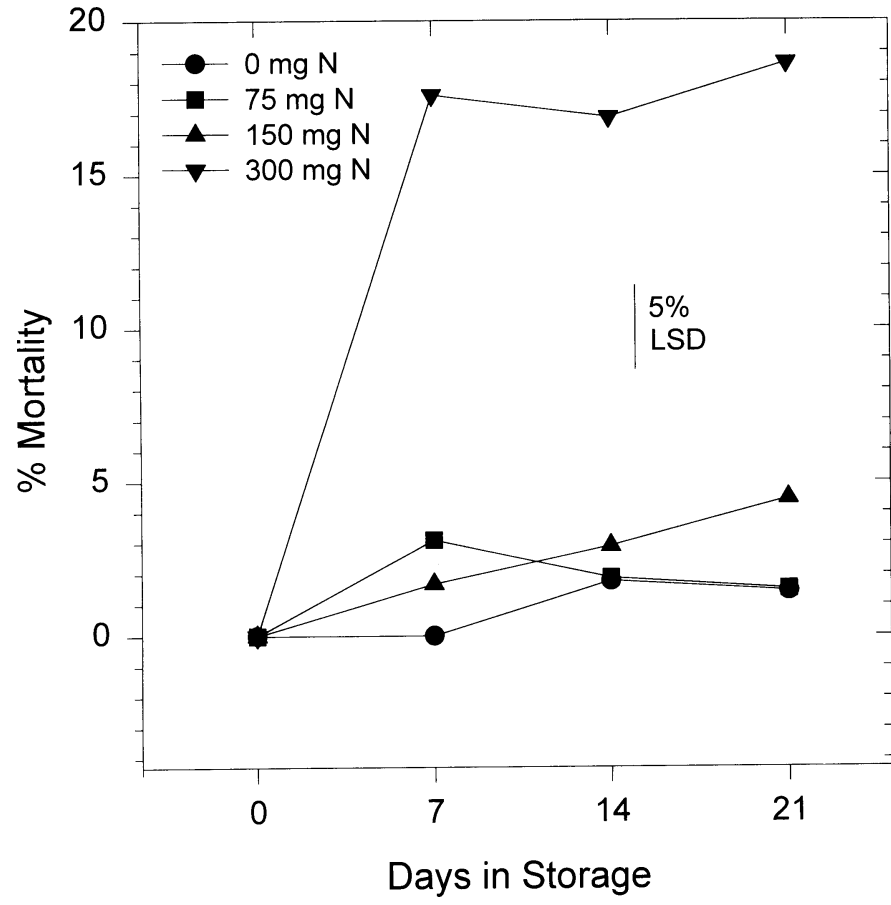

Fig. 1. Seedling mortality rates in Pelargonium $\times$ hortorum preconditioned with $0,75,150$, or $300 \mathrm{mg} \mathrm{N} /$ liter for 14 days before storage and stored for $0,7,14$, or 21 days.

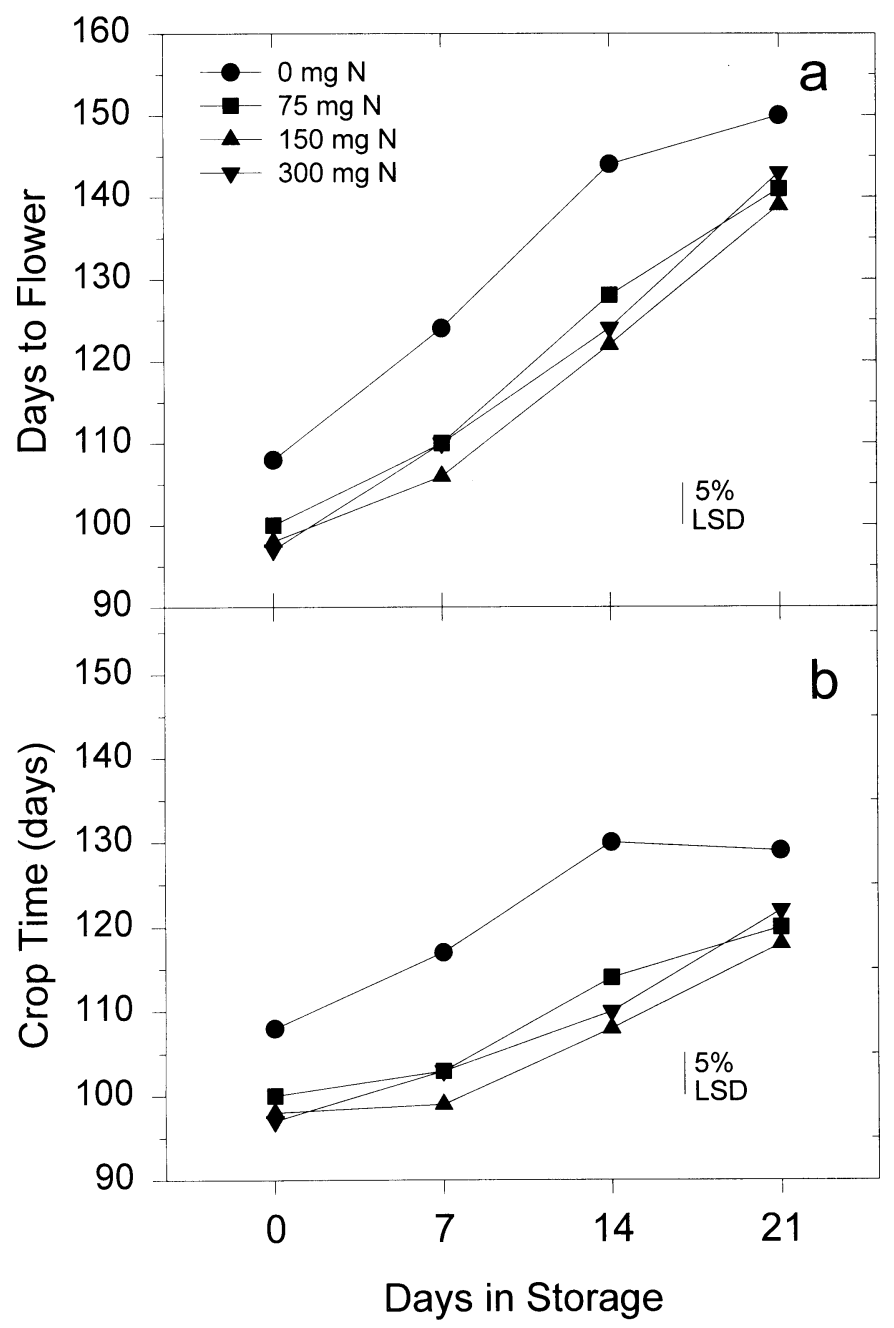

Fig. 2. (a) Days to flower and (b) crop time for Pelargonium $\times$ hortorum preconditioned with $0,75,150$, or $300 \mathrm{mg} \mathrm{N} /$ liter for 14 days before storage and stored for $0,7,14$, or 21 days. to grow under low temperatures (Kaczperski et al., 1991), whereas geranium growth slows at low temperatures and ceases below 10C (Fonteno, 1992; Koranski and Khademi, 1993). Seedling development was delayed during the storage period.

Preconditioning geranium seedlings by reducing the growing temperature before storage delayed flowering (Fig. 3a). Flowering of unstored seedlings preconditioned at $10 \mathrm{C}$ was delayed 11 days compared to that of seedlings preconditioned at 20C. Seedlings stored 7 days flowered 15 days later when preconditioned at 10 instead of 20C. Flowering can be delayed in geraniums when seedlings are exposed to temperatures below $15 \mathrm{C}$ for $>1.5$ weeks (Koranski and Khademi, 1993). Preconditioning plants at $10 \mathrm{C}$ reduces growth during the preconditioning period, resulting in delayed flowering.

Days in the production environment increased with low-temperature preconditioning (Fig. 3b). However, the number of days in the production environment was unaffected by seedling storage of 7 or 14 relative to 0 days when preconditioned at the same temperature. Similar results were reported for other geraniums (White and Quatchak, 1985) and petunias (Kaczperski and Armitage, 1992).

Preconditioning by altering temperature did not affect final plant appearance, final plant height, or dry weight. Longer time in the production environment increased plant height and dry weight regardless of the preconditioning treatment.

Geranium seedlings tolerated stress common in storage or shipping if preconditioned. Lowering the fertility level before stressing the plants did not adversely affect final plant quality. Compared to $150 \mathrm{mg}$ N/liter, preconditioning fertility levels of 0 or $75 \mathrm{mg} \mathrm{N} /$ liter delayed flowering after plants were removed from storage, which increased the crop time and, presumably, the cost of production. At $300 \mathrm{mg} \mathrm{N} /$ liter, plant growth apparently became too soft to withstand stress, resulting in high seedling mortality. Preconditioning geranium seedlings with temperature before stressing the plants increased production time at relatively low temperatures. Adequate results can be attained by using $150 \mathrm{mg}$ N/liter before stressing plants. Seedlings preconditioned in this manner will have the least delay in flowering, and will not produce the soft growth more susceptible to disease during storage.

\section{Literature Cited}

Al-Hemaid, A.I. and D.S. Koranski. 1990. Temperature, transplant time, and plug size effects on growth and development of pansy, petunia, vinca, and impatiens. HortScience 25:1159. (Abstr.)

Armitage, A.M. and M.P. Kaczperski. 1992. Seedpropagated geraniums and regal geraniums. Timber Press, Portland, Ore.

Armitage, A.M. and T. Kowalski. 1983a. Effects of light intensity and air temperature in simulated postproduction environment on Petunia hybrida Vilm. J. Amer. Soc. Hort. Sci. 108:115-118.

Armitage, A.M. and T. Kowalski. 1983b. Effect of irrigation frequency during greenhouse produc- 


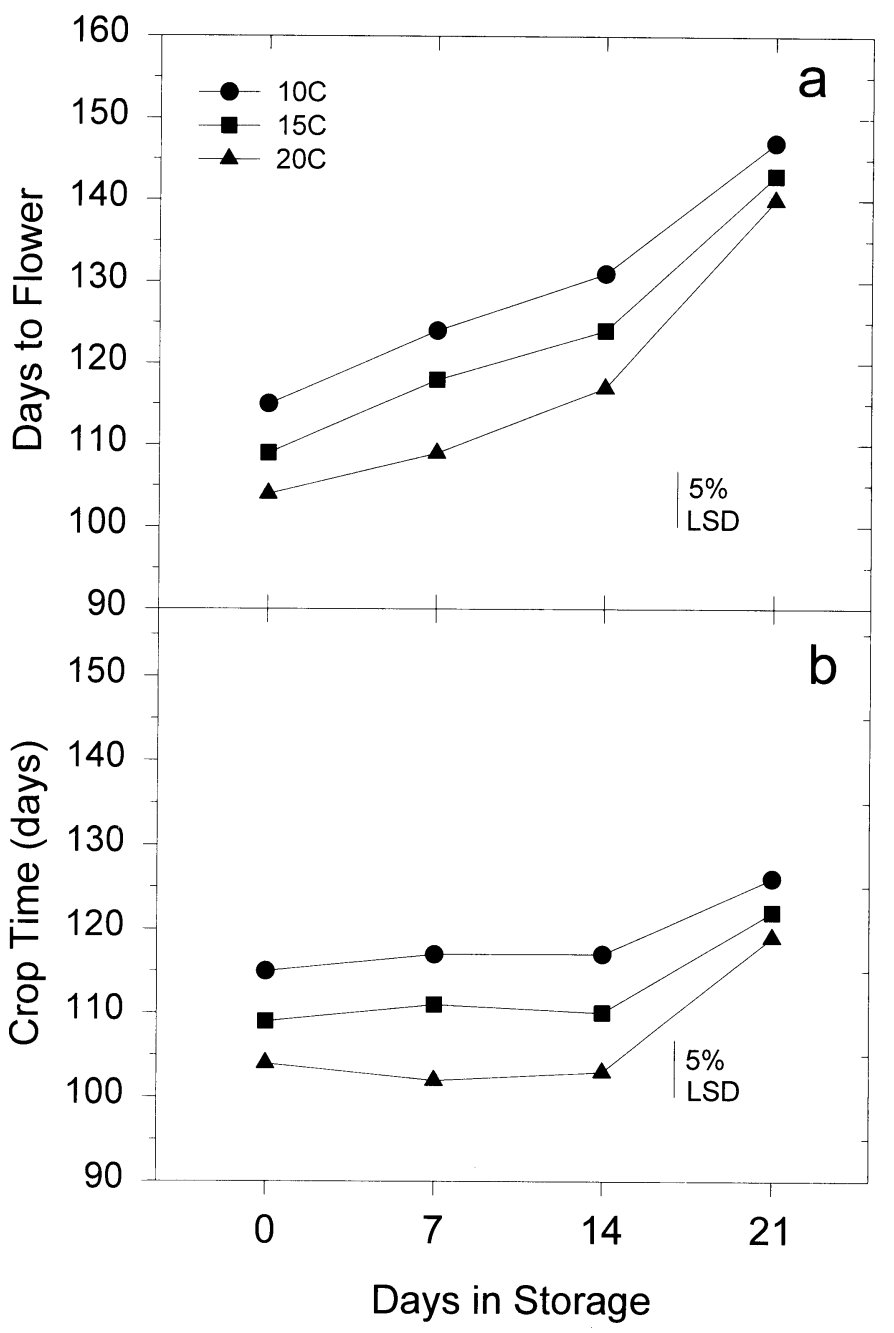

Fig. 3. (a) Days to flower and (b) crop time for Pelargonium $\times$ hortorum preconditioned at 10, 15, or $20 \mathrm{C}$ for 14 days before storage and stored for $0,7,14$, or 21 days. tion on the postproduction quality of Petunia hybrida Vilm. J. Amer. Soc. Hort. Sci. 108:118 121.

Carlson, W.H., M.P. Kaczperski, and E.M. Rowley. 1992. Bedding plants, p. 511-550. In: R.A. Larson (ed.). Introduction to floriculture. Academic, New York.

Fonteno, W.C. 1992. Geraniums, p. 451-475. In: R.A. Larson (ed.). Introduction to floriculture. Academic, New York.

Gladstone,L.A. and G.W. Moorman. 1989. Pythium root rot of seedling geraniums associated with various concentrations of nitrogen, phosphorus and sodium chloride. Plant Dis. 73:733-736.

Heins, R.D., M.P. Kaczperski, T.F. Wallace, Jr., N.E. Lange, W.H.Carlson, and J.A. Flore. 1995. Low-temperature storage of bedding plant plugs. Acta Hort. 396:285-296.

Holcomb, E.J. and J.W. White. 1987. Duration in plug cells affects growth and flowering of geraniums. Applied Agr. Res. 2:350-353.

Hopper, D.A. and W.H. Carlson. 1985. Plugs: Less space, less time. Grower Talks 48(9):48-54.

Kaczperski, M.P. and A.M. Armitage. 1992. Shortterm storage of plug-grown bedding plant seedlings. HortScience 27:798-800.

Kaczperski, M.P., W.H.Carlson, and M.G. Karlsson. 1991. Growth and development of Petunia $\times$ hybrida as a function of temperature and irradiance. J. Amer. Soc. Hort. Sci. 116:232-237.

Koranski, D.S. and M. Khademi. 1993. Plug culture, p. 113-123. In: J.W. White (ed.). Geraniums IV: The grower's manual. Ball Publishing, Geneva, Ill.

Lange, N., R. Heins, and W. Carlson. 1991. Store plugs at low temperatures. Greenhouse Grower 9(1):22-28.

McCann, K.R. 1991. Toning techniques to help your plants weather the stress of shipping. Greenhouse Grower 9(3):42, 44, 46.

Nell, T.A. and J.E. Barrett. 1990. Post-production handling of bedding and potted plants. Acta Hort. 272:311-317.

White, J.W. and D.J. Quatchak. 1985. Cool storage of plug grown geranium seedlings. GrowerTalks $48(10): 68-71$ 